\title{
Dolphinfish fisheries in the Caribbean region*
}

\author{
ROBIN MAHON \\ Fisheries and Environmental Consulting, 48 Sunset Crest, St. James, Barbados. E-mail: rmahon@caribsurf.com
}

\begin{abstract}
SUMMARY: Dolphinfish are targeted throughout the Western Central Atlantic region by recreational fishers, small-scale artisanal fishers, and small longliners. They are also taken as by-catch on large-scale commercial longlines. Catches are highly seasonal and exhibit considerable interannual variability. According to the landing statistics provided by countries to FAO, dolphinfish ranked seventh overall in reported average annual landings of large pelagic fishes in the Western Central Atlantic from 1989 to 1993 . Yellowfin tuna, Spanish mackerel, skipjack tuna, king mackerel, swordfish and Atlantic bonito ranked ahead of dolphinfish. There is a trend of increasing total annual landings from about 1,700 mt in 1970-74 to about 2,800 mt in 1989-1993. Landings are reported to FAO by only eight countries, whereas dolphinfish are known to be caught in most of the region's 34 countries. By-catch on longlines and recreational landings are also largely unreported. Therefore, it is likely that the reported landings are a substantial underestimate. The relative importance of dolphinfish to pelagic fisheries varies from one part of the region to another. In the Lesser Antilles it is the most important large pelagic fish in terms of amounts landed. The absence of a large-scale commercial fishery targeting dolphinfish appears to have resulted in a lack of recognition of its contribution, particularly in developing countries of the region. Consequently, its biology and assessment have been neglected in relation to the attention given to other large pelagic fishes, mainly tunas and tuna-like fishes which have been the focus of ICCAT assessment activities.
\end{abstract}

Key words: dolphinfish, Caribbean, large pelagic

\section{INTRODUCTION}

The "Wider Caribbean" area includes the Caribbean Sea, the Gulf of Mexico, the northeast coast of South America and the southeastern Atlantic coast of the USA. This is also the area referred to as the Western Central Atlantic (WCA) by FAO. It is their Fishery Statistical Area 31. The Western Central Atlantic Fishery Commission (WECAFC) covers all of this area as well as some of Fishery Statistical Area 41 to the south (to $10^{\circ} \mathrm{S}$, and to $30^{\circ} \mathrm{W}$ ) (Fig. 1).

The oceanography of the Caribbean region is highly variable both spatially and temporally. Four

\footnotetext{
*Received January 5, 1998. Accepted October 15, 1998.
}

of the largest river systems in the world - the Amazon, Orinoco, Rio Grande and Mississippi Rivers have a considerable influence on the north coast of South America and the Gulf of Mexico (MullerKarger, 1993). Most Caribbean islands are more affected by the nutrient-poor North Equatorial Current, which enters the Caribbean Sea through the passages between the Lesser Antilles. Those islands with appreciable shelf area exhibit significant coral reef development. From Isla Margarita west to Mexico, the continental shelf is also extensively occupied by coral reefs at shallow depths. Seagrass beds and mangroves are also common coastal habitats.

There is no current comprehensive review of Caribbean fisheries. However, an overview can be obtained from some early reviews (Klima, 1976; 


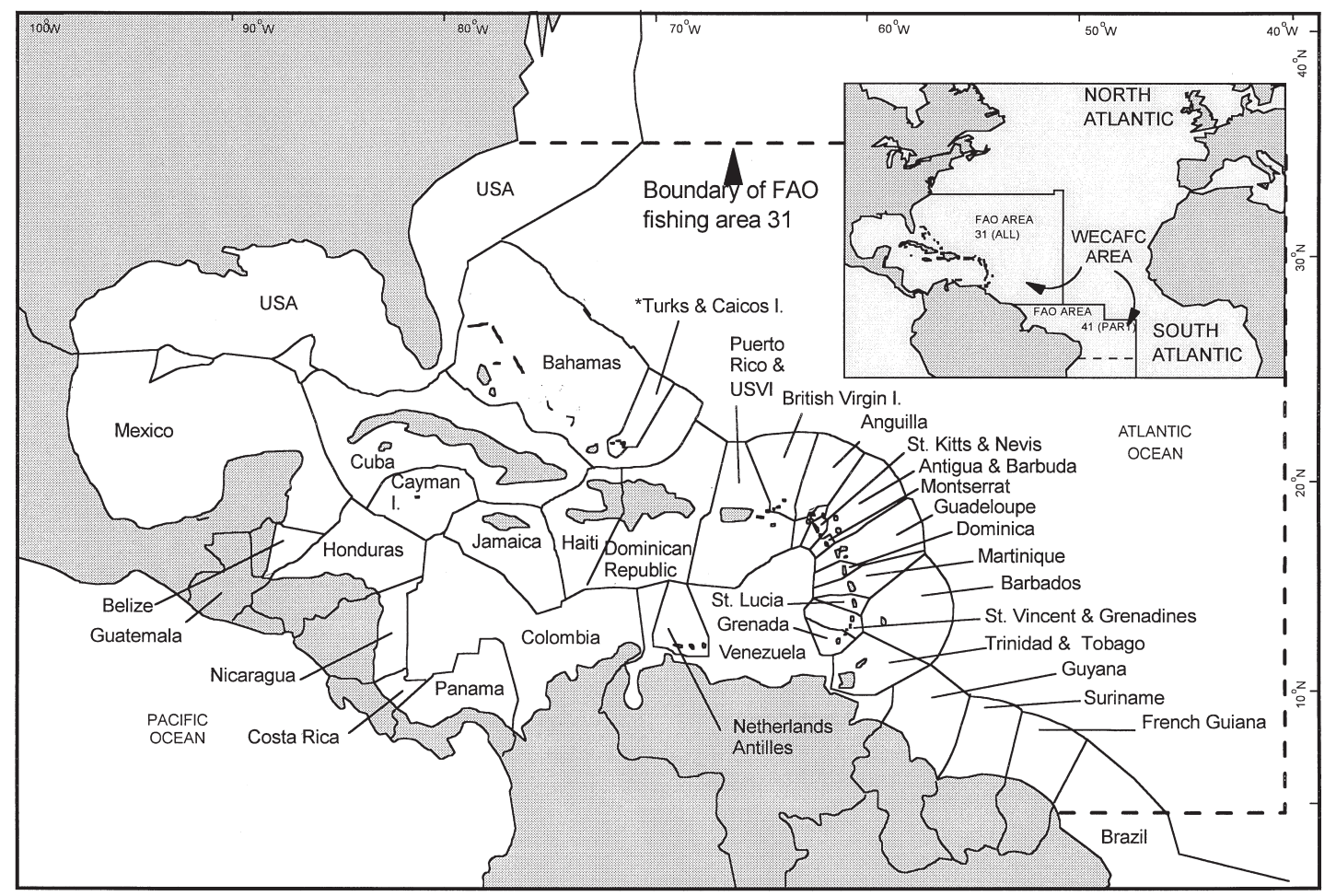

FIG. 1. - The wider Caribbean region and Western Central Atlantic Fishery Commission area showing approximate EEZs of countries (adapted from Mahon, 1996).

Stevenson, 1981) and from some recent ones that address particular geographical areas or resource types (Mahon, 1990; Oxenford, 1991; FAO, 1993; Mahon, 1996).

The fisheries of the Caribbean Region are based upon a diverse array of resources. The fisheries of greatest importance are for offshore pelagics, reef fishes, lobster, conch, shrimps, continental shelf demersal fishes, deep slope and bank fishes and coastal pelagics. There is a variety of less important fisheries such as for marine mammals, sea turtles, sea urchins, and seaweeds. These fishery types vary widely in state of exploitation, vessel and gear used, and approach to their development and management. The relative importance of these fisheries varies widely among the countries, depending mainly on the amount of coastal shelf and whether the shelf habitats are mainly coral reefs or river discharge influenced.

In general, shelf resources (e.g. lobster, conch, reef fish, shrimps) are either fully exploited or already overexploited, particularly near shore (FAO, 1993; FAO, 1994). Optimizing the returns from these resources will require rehabilitation and management.

In the Western Central Atlantic, large pelagic fishes comprised only $4 \%$ of total fishery landings between 1986-1990 (Mahon, 1996). However, these resources, mainly tunas and swordfish, are considered by most countries to hold some potential for development. During the period 1989-1993, dolphinfish ranked seventh in importance by weight amongst reported landings of large pelagic fishes from this region (3.3\% by weight) (Mahon, 1996). The relative importance of dolphinfish appears to vary considerably from one part of the region to another in the period 1989-1993. Distant water fleets fishing in the area do not report any dolphinfish landings. Nor do countries of South and Central America. For the USA and Mexico the dolphinfish contribute only $2.6 \%$ of landings of large pelagics. For the Greater Antilles the percentage is 4\%, whereas for the Lesser Antilles it is 40\% (Mahon, 1996).

\section{TRENDS IN FISHING EFFORT FOR LARGE PELAGICS}

There are no commercial fisheries outside of the USA that target dolphinfish exclusively, although in some fisheries dolphinfish may be the main species caught. Dolphinfish are generally only one component of multispecies fisheries for large pelagics. At times, they are only by-catch in fisheries directed at 
tuna and swordfish. Therefore, in order to evaluate trends in fishing effort that may affect dolphinfish, it is necessary to consider trends in overall effort for large pelagic species. In this section I examine trends in fishing fleets, gear and, where possible, fishing effort for the various types of fisheries which target large pelagics in the WECAFC Region. I follow the categorisation of large pelagics into coastal species (Scomberomorus spp., dolphinfish, cobia ) and oceanic species (swordfish, billfishes, yellowfin tuna, bluefin tuna, bigeye tuna, albacore, skipjack tuna, Atlantic bonito, Atlantic black skipjack tuna, frigate tuna, wahoo) used by the US National Marine Fisheries Service (NMFS) Southeast Fisheries Science Center (SEFSC) (SEFSC, 1994).

\section{Artisanal and small-scale fleets}

Large pelagic species have been exploited by local artisanal and small-scale fishers throughout the Caribbean from the earliest recorded times (e.g. Brown, 1945; Caribbean Commission, 1952). In most countries these fisheries were coastal, using small vessels such as canoes and pirogues for trolling. These methods continue to be used in many countries, but there have also been intermittent improvements in vessels and gear in several countries.

Estimates of the numbers, types and activities of artisanal/small-scale vessels are widely scattered throughout the literature. Since most of the small vessels are used to fish a variety of species, estimates of the numbers of these vessels do not accurately reflect the fishing effort being directed at large pelagic fishes in general, or dolphinfish in particular. Availability of many large pelagic species is highly seasonal, particularly to artisanal vessels which do not venture far from shore (e.g. Mahon et al., 1990). Therefore, during the off-season, vessels may fish for demersal species, or small coastal species. Even within a single fishing trip, fishing effort may be divided between fishing for demersals and pelagics. In islands of the southeastern Caribbean, the focus of a trip may be primarily large pelagic fishes, or during the flyingfish season a combination of this species (Hirundichthys affinis) and large pelagics. In other countries of the region, with more extensive coastal shelves and associated demersal fisheries, similar vessels may fish for large pelagics only incidentally while travelling to and from demersal fishing areas, or may occasionally focus on large pelagics when they are available.
In the southeastern Caribbean small-scale fishers depend upon the association of dolphinfish and other pelagics with drifting objects (Gomes et al., 1988). Most fishers interviewed in Barbados, Tobago, Grenada, St. Vincent and St. Lucia reported seeking drifting objects on fishing trips. Dolphinfish did not seem to have a preference for any particular type of drifting object, being equally attracted to natural objects and those of human origin.

Details of fishing for dolphinfish in Barbados are provided by Oxenford (1985). For trolling, flyingfish is the preferred bait. The method of fishing a school of dolphinfish found under a drifting object is described, including keeping one live fish on a short line near the boat to keep the school nearby.

Despite the lack of quantitative information on trends in numbers of various types of vessels, recent development trends in local fleets in the eastern Caribbean do indicate that there is a trend of increasing artisanal and small-scale fishing effort directed at these large pelagic species. The cases presented below illustrate trends in the development of fleets and fishing effort for large pelagics that are assumed to be similar to those taking place in countries throughout the region.

In Grenada, in the Lesser Antilles, longline fishing for pelagics, introduced in the early 1980s with assistance from Cuba, was adopted by the troll fishing fleet on the island's west coast. By 1993 there were 110 converted, or locally purpose-built, small longliners fishing 1-day trips, and seven Japanesebuilt short-stay longliners (Samlalsingh, 1995). In addition to the increased number of vessels, there were considerable changes in the size of vessels, gear used and fishing power. Over the 10 year period of development of these vessels, the catch per trip of target species increased from 43 to $120 \mathrm{~kg}$.

The neighboring countries of St. Vincent and the Grenadines and St. Lucia have also emphasised an increasing harvest of large pelagic fishes. Both have seen recent increases in fishing capacity. In St. Lucia, 40 new $9 \mathrm{~m}$ vessels (not all fishing for large pelagics) and 5 new $15 \mathrm{~m}$ longline vessels were introduced between 1989 and 1992. In St. Vincent and the Grenadines five new $12.5 \mathrm{~m}$ multipurpose vessels equipped with longline and trolling gear were acquired from Japan in 1991 (Mahon and Singh-Renton, 1992). Previously, the fleet in St. Lucia consisted of about 300 canoes and skiffs, 5-8 $\mathrm{m}$ in length, while that fishing for large pelagics in St. Vincent and the Grenadines consisted of pirogues 6-8 $\mathrm{m}$ in length (Mahon and Rosenberg, 1988). 
Several other Lesser Antillean countries, members of the Organization of Eastern Caribbean States, reported initiatives aimed at increasing pelagic fishing, ranging from the introduction of longline gear on artisanal vessels to the acquisition of new small-scale longline vessels (OECS, 1992).

Trinidad and Tobago has also increased its longline fleet. In 1988 two locally owned longline vessels began surface longlining. By 1992, eight vessels (14-23 $\mathrm{m}$ in length) were in operation (Mahon and Singh-Renton, 1992).

Recently there has also been a significant expansion in the fishing capacity for large pelagics in Barbados. Between 1962 and 1979 the number of vessels fishing for pelagic fishes (flyingfish and large pelagics) was relatively constant at about 400 . However, during that period the fishing power of these day-trip trolling vessels more than doubled from $35 \mathrm{~kg} /$ day to $76 \mathrm{~kg} /$ day due to increased boat and engine size (Oxenford and Hunte, 1987; Mahon et al., 1990). In 1979, the development of a new fleet of larger vessels with ice holds, capable of staying at sea for 7-14 days, and thus fishing further from base, began with the introduction of one vessel. By 1989, 82 such vessels were in operation. Most were locally built and many were equipped with longline gear. Towards the end of this period, there were several joint ventures with USA vessel owners. Barbados remains committed to further development of its longline fleet.

In Venezuela, there are two artisanal fleets that have increasingly targeted dolphinfish in recent years. There is a gillnet fleet in the central coastal area, and a longline fleet operating from Isla Margarita in the east. Details of these fleets and their fishing operations are provided by Arocha et al. (1999). These fleets have recently begun to target dolphinfish, showing a steady increase in landings from 1991 to 1997.

Most of the information on catches and catch rates of dolphinfish in the eastern Caribbean is based on vessels which employ the more traditional method of trolling. The proportions of dolphinfish caught by the small longliners that have recently been introduced in many countries has seldom been documented. A US swordfish longline vessel fishing in the vicinity of Grenada reported only $0.3 \%$ of its catch by weight as dolphinfish (Mahon, 1993). In local vessels targeting surface species, mainly yellowfin tuna and sailfish in Grenada fishing at depths of $30-90 \mathrm{~m}$, the proportion of dolphinfish was higher, being in the range of 3-5\% (Samlalsingh, 1995; Samlalsingh et al., in press).

\section{Large-scale commercial}

Large-scale commercial fleets have been fishing for large pelagics in the Caribbean region since the late 1950s. Most of the fishing effort has been by longliners, but since the early 1970s there have been purse seine and tuna pole and line vessels as well. There is little documentation regarding the catches of dolphinfish by large-scale commercial fleets targeting tunas with longlines, purse seines and pole and line.

The US swordfish fleet which expanded its operations throughout the Caribbean over the period 1987-1993, reports an overall by-catch of dolphinfish of 2.66 fish/1,000 hooks (data provided by the US National Marine Fisheries Service, Southeast Fisheries Science Center (NMFS SEFSC). Considerable further analysis of these data are required to determine the spatial and seasonal variation in dolphinfish catches.

The ICCAT database provides the best available information on fishing effort by large-scale commercial fisheries in the western central Atlantic. The database includes fishing effort and catch by country, gear, year, month and square $\left(10^{\circ}, 5^{\circ}\right.$ or $1^{\circ}$ on the side). Most data for longliners are recorded by $5^{\circ}$ squares and those for surface fisheries by $1^{\circ}$ squares. Trends in fishing effort are shown by country for longlines, purse seines and bait boats (Fig. 2). In the case of longlines, the trends are shown for two sets of squares, (1) those in the Atlantic, mainly to the east of national EEZs, and (2) those mainly in the area of national EEZs (Fig. 2). This analysis follows that presented by Mahon (1996).

In the late 1950s, there was a steady increase in Japanese longline fishing effort in the western central Atlantic from 1958 through 1966, in both groups of squares. The decline in Japanese effort in the late 1960s was accompanied by an increase in Taiwanese longline effort from 1967 to the mid-1970s in both areas, and in Korean longline effort from 1974 through 1979. The fleets comprising this succession of peaks were targeting yellowfin tuna. There was a second peak in Taiwanese effort in this area in 1986, primarily in the Atlantic to the east of the EEZs, targeting albacore. In later years, longline activity by Cuba is concentrated mainly between 1984 and 1987. The growth of Venezuela's large commercial fleets shows clearly from 1981 to 1985 , and the increased activity of swordfish vessels from the USA is evident from 1986 onward (Fig. 2). The distribution of longline fishing effort by $5^{\circ}$ square in 


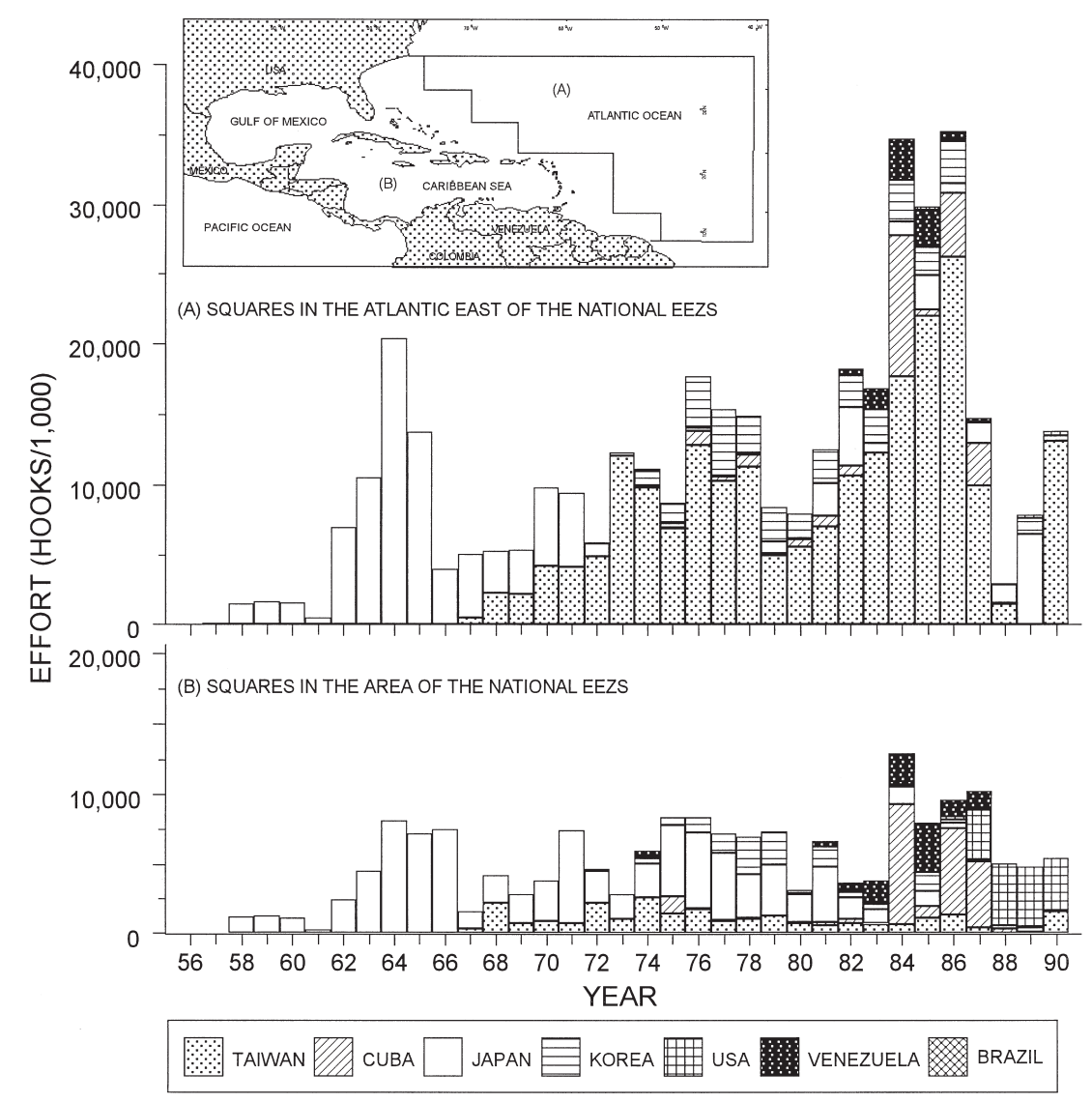

FIG. 2. - Trends in longline fishing effort by countries reporting landings in the WECAFC area. The data are shown for two areas: (A) data reporting squares in the Atlantic east of national EEZs; and (B) squares in the area of national EEZs.

the WECAFC area for all countries combined for the period 1986-1990 shown by Mahon (1996) suggests that longline effort and catch in the Caribbean Sea are low in comparison to that in the Atlantic Ocean east of the island arc.

The Venezuelan tuna fishing fleet includes large purse seiners, small and large longliners and small baitboats. The Venezuelan purse seine tuna fishing fleet only began to expand rapidly in the early 1980 s, increasing from five vessels in 1982, with a capacity of 5,600 short tons, to 25 vessels in 1988 , with a capacity of 29,700 tons Weidner and Hall (1993). These vessels range in size from 900-1,500 gross registered tons (GRT). The purse seine fleet fishes mainly in the eastern tropical Pacific, but does catch appreciable amounts of tuna in the western central Atlantic.

In 1992, the Venezuelan longline fleet consisted of two large longliners (about $60 \mathrm{~m}$ ), which operate primarily in the western Atlantic, and about 80 small vessels $(20-25 \mathrm{~m})$ using about $33 \mathrm{~km}$ of longline. The small-scale fleet in general appears to be expanding, as there were only 58-60 vessels operat- ing in 1990-1991. The exact number of these which target tuna is uncertain, with reports ranging from 15 to 33 vessels (Weidner, 1993). Eslava and Gaertner (in press) report four large longliners and only 15 small ones, noting that the latter fleet had declined recently due to difficult economic times in Venezuela. Arocha et al.(1999) report that dolphinfish have been a component of the by-catch of the longline fleet since the 1960s.

Cuba's tuna fleet, of 1 purse seiner and 10 longliners over 500 GRT reported to be operating in 1989 , is believed to have been fishing primarily off West Africa. However, some activity by Cuban longliners was reported in the WECAFC area between 1984 and 1987. Details of the small-scale domestic fleet which fishes for large pelagics in the vicinity of Cuba are not readily available. Rodriguez (1989) indicates that there were about 60 small-scale pole and line fishing vessels and about 80 smallscale longliners in operation in Cuba in 1988.

Most commercial fishing for large pelagics in the WECAFC area by the USA is by small-scale fleets for coastal pelagics. Two notable exceptions are the 
longline fleet fishing for yellowfin tuna in the Gulf of Mexico (Browder and Scott, 1992), and the swordfish longline fleet. The latter shifted its operations south through the Caribbean and down to the north coast of South America from about 1986 through 1991 and withdrew partially in subsequent years.

\section{Recreational}

Throughout the Caribbean, dolphinfish are an important component of recreational fishing. There are few records of quantities caught by recreational fishers. Furthermore, the lack of information on the numbers of recreational vessels and their patterns of fishing makes it impossible to estimate the catch of this component of the fishery. A questionnaire survey by Schmeid (1989) is the most complete compilation of information for the countries of the wider Caribbean. Of 40 countries/islands surveyed, 27 replied, but many respondents were unable to supply quantitative information on the numbers of anglers (12/27 respondents provided), private vessels (17/27) or charter vessels (19/27) present in their countries.

Recreational fishing can be considered in three parts: fishing tournaments; charter boat fishing, usually by tourists; and regular fishing from privately owned pleasure craft (private fishing). There are local and international fishing tournaments for large pelagics throughout the Caribbean region. Many of these are aimed at billfish, but other species are also often caught. Between 1991 and 1994, 18\% of the catch at the St. Lucia Annual International Billfish Tournament was dolphinfish (De Beauville-Scott, in press).

In a questionnaire survey of Caribbean countries, 11 of 18 countries listed dolphinfish as one of the top five marine species sought in tournaments, whereas 10 of 20 countries listed it as one of the top five species caught (Schmied, 1989). In Puerto Rico, in a 1978 survey, dolphinfish was named as the most sought after sport fish (CFMC, 1983).
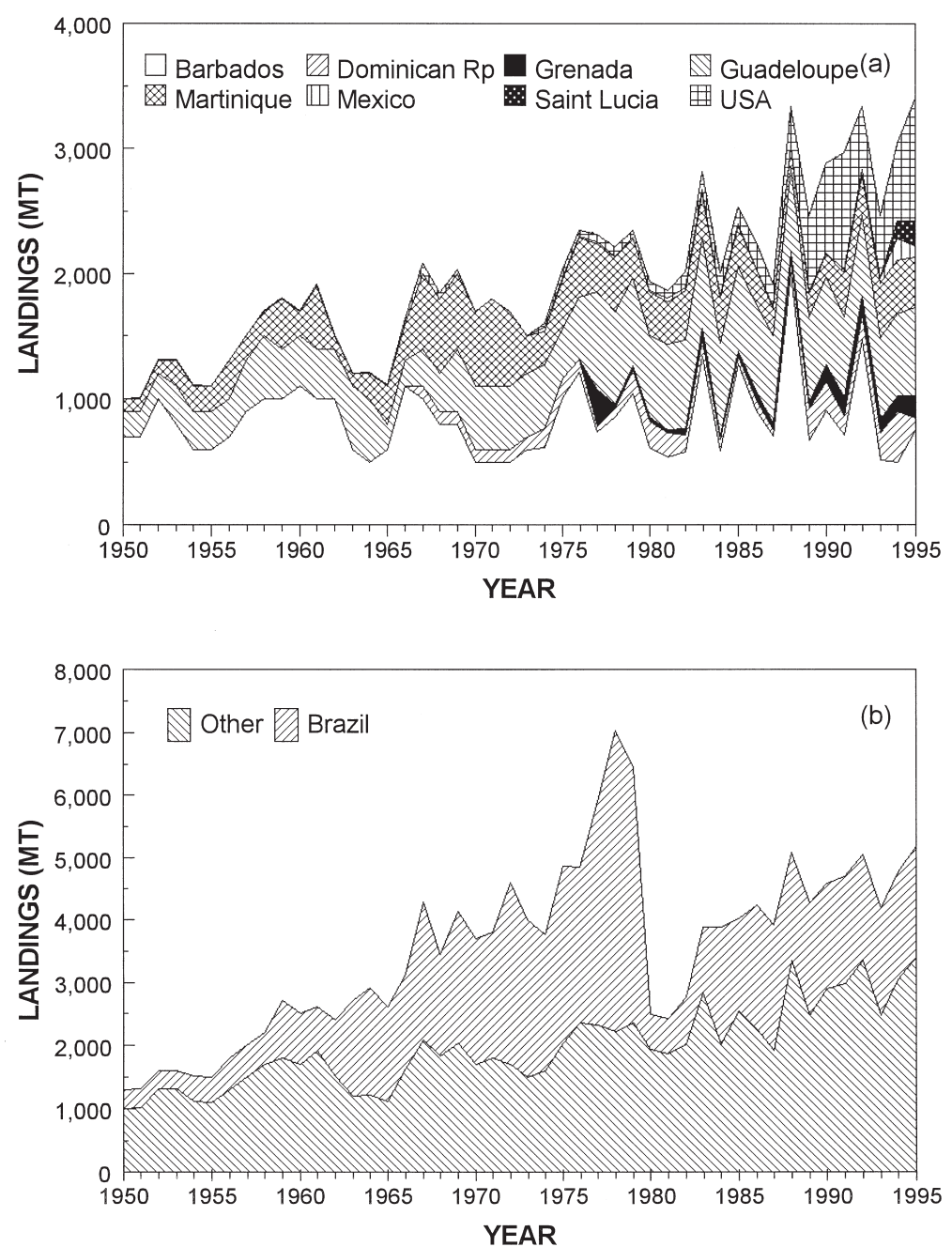

FIG. 3. - Reported dolphinfish landings from the Western Atlantic: (a) Caribbean countries, and (b) from Brazil and the total for all Caribbean countries. 
TABLE 1. - Dolphinfish fisheries in countries of the wider Caribbean region ( $\mathrm{R}=$ recreational, $\mathrm{A}=$ artisanal, $\mathrm{C}=$ commercial). For countries not reporting dolphinfish, landings of unidentified fishes that could include dolphinfish are shown in three categories: unidentified marine fishes (UIM), unidentified pelagic fishes (UIP) and unidentified tuna-like fishes (UIT).

\begin{tabular}{|c|c|c|c|c|}
\hline Country & Fisheries & $\begin{array}{l}\text { Dolphinfish } \\
\text { landings } \\
\text { Period }\end{array}$ & $\begin{array}{l}\text { Avg. ann. unid. } \\
\text { landings (1990-94) }\end{array}$ & Comments and sources \\
\hline
\end{tabular}

\begin{tabular}{lccc}
\hline \multicolumn{4}{l}{ Countries reporting dolphinfish landings to FAO } \\
Barbados & RAC & 821 & $1990-1994$ \\
Dominican Republic & RAC & 242 & $1990-1994$ \\
Grenada & RAC & 135 & $1990-1994$ \\
& & & \\
Guadeloupe & RAC & 656 & $1990-1994$ \\
Martinique & RAC & 345 & $1990-1994$ \\
Mexico & RAC & 59 & $1990-1994$ \\
USA & RC & 657 & $1990-1994$
\end{tabular}

Countries not reporting dolphinfish landings to FAO

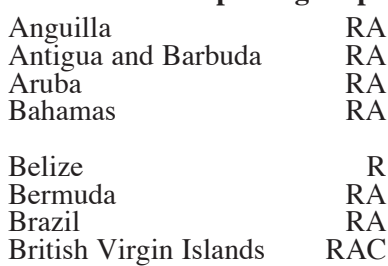

Cayman Islands

Colombia

$\mathrm{R}$

15
92

1992

1993

119

3386

2684

UIM

112 UIM

884 UIM

232 UIM

466 UIP

115 UIM

384 UIM

119 UIM

UIM

934 UIM

Costa Rica

Cuba

$\mathrm{R}$

Dominica

RAC

72

1992

65

22096

UIM
UIM

French Guiana

Guatemala

Guyana

Haiti

Honduras

Jamaica

Montserrat

Netherlands Antilles

Nicaragua

(

$\mathrm{RAC}$
$\mathrm{R}$

$\mathrm{R}$

Puerto Rico

RAC

St. Kitts/Nevis

St. Lucia

RAC

R Neg

677

UIM

3171

UIM

$\mathrm{R}$

$\mathrm{Neg}$

102

35969

UIM

RA

RAC

110

535 UIM

$\begin{array}{lll}1981 & 7200 & \text { UIM }\end{array}$

St. Vincent/Granadines

RAC

Suriname

Trinidad/Tobago

Turks and Caicos Islands US Virgin Islands
About 50\% of total landings (Oxenford, 1985)

FAO. No details provided by Appeldoorn and Myers (1993)

Comprised $17.9 \%$ of large pelagic landings at Grenville, east coast, and $8.0 \%$ and $7.2 \%$ at west coast sites 1981-1989 (Mahon et al., 1990) FAO

Comprised 9\% of large pelagic landings (Sacchi et al.,1981)

FAO

FAO

No specific information on dolphinfish (MRAG, 1993)

Important in recreational fisheries only (Bahamas Dept. Fish., 1992)

No specific information in MRAG (1993), $0.9 \mathrm{mt}$ landed at BVI Fishing Co. Ltd. In 1987, comprising $0.9 \%$ of fish landed at that facility, mainly incidental catch to reef fish fishery. Recreational fisheries mentioned by Walters (1983)

Not listed by MRAG (1993).

Dolphinfish was second most important species in the artisanal catch in 1993 (11\%) (INPA, 1993, 1994). Listed as incidental catch in deepwater fishery, but not as a major species in fisheries around San Andres/Providencia archipelago (Mow de Peters, 1988)

No mention in Paez (1991) or Baisre (1993). Former gives annual landings down to $0.3 \mathrm{mt}$. Dolphinfish are mentioned by Roig and de la Maza (1952)

Comprised $12.1 \%$ ( $25 \mathrm{mt}$ ) and 13.\% (65 mt) of total landings in 1984 and 1985 (Anon. 1985, 1986). 1992 catch from Guiste et al. (1996)

No reports of dolphinfish. Unlikely in nearshore fisheries due to river influences.

Dolphinfish are not taken by domestic fisheries (Phillips and Charles, 1993)

No mention of dolphinfish by Appeldoorn and Myers (1993)

Comprised $6 \%$ (34 mt) of pelagic and $0.03 \%$ of total landings in $1963,3.6 \%$ (27 mt) of pelagic and $0.2 \%$ of total in 1970 , and $25 \%$ of pelagic and $1.5 \%$ of total in 1981 (Sahney, 1983, Mahon, 1995)

MRAG, (1993)

Zaneveld (1962)

No mention in Garcia (1989) which includes spp. with landings down to $0.1 \mathrm{mt}$

CFMC (1983), Appeldoorn and Myers (1993), Perez et al. (1993)

Mentioned by Olsen (1983)

$19 \%$ of total landings in 1993 (Gobert and Domalain, 1995), and $43.2 \%-36.0 \%$ of pelagic landings from 1984-1989 (Mahon et al., 1990).

Comprised $38.2 \%$ of pelagic landings from 1979-1989 (Mahon et al., 1990). 1995 landings from OECS (1996) No catches of dolphinfish have been noted (Charlier, 1993)

Mentioned as a recreational species but not listed as a commercial species by Kenny and Bacon (1983)

Not listed as a species caught by longlines (MRAG 1993). Comprised $6.9 \%$ of recreational catch (Olsen and Wood, 1983). Comprised 7\% (1.4 mt), 4\% (1.2 mt) and 16\% (3.6 mt) of recreational catch in St. Thomas in 1983, 1984 and 1985 (Brandon, 1988). CFMC (1983), Appeldoorn and Myers (1993) Arocha et al. (1999). Not included in Herrera-Teran (1988), which lists species with landings down to $1 \mathrm{mt}$. Recreational importance in Machado and Jaen (1983) 
Dolphinfish are also a significant component of private fishing. In Venezuela, records from a single yacht club show that between 1961 and 1981 dolphinfish comprised $17.6 \%$ (numbers) of the catch (Machado and Jaen, 1983). In Puerto Rico in 1979 the percentage (numbers) was $14.33 \%$ (CFMC, 1983).

\section{Fish attracting devices (FADS)}

Despite the tendency for dolphinfish and other large pelagics to occur in association with drifting objects (Oxenford, 1985; Gomes et al., 1998), FADs are not in common use by commercial or recreational fishers in the Caribbean (Gomes et al., 1998). There have been some studies of the efficacy of FADs in the Caribbean area. Friedlander (1992) found that the majority of fish caught trolling around FADs were dolphinfish (64.2\%), and catch rates were higher than in a control area. Commercial and recreational fishers report increased catch rates for dolphinfish when trolling around FADs placed off the west coast of Barbados (pers. com. S. Willoughby, Barbados Fisheries Division).

\section{TRENDS IN LANDINGS}

There is an overall increasing trend in dolphinfish landings reported to FAO by countries in the Western Central Atlantic (Fig. 3). However, only eight of about 34 states report dolphinfish landings (Table 1). Brazil also reports a steady increase in landings from the southwest Atlantic. However, this appears to have been in two phases, with a steep increase in 1950-1978, followed by a sharp drop in 1978-1980, and another period of increase through to 1995 (Fig. 3). Although Venezuela does not report dolphinfish landings, Arocha et al. (1999) provide estimates of landings showing an increasing trend from $50 \mathrm{mt}$ in 1990 to $607 \mathrm{mt}$ in 1997.

Dolphinfish are known to be caught in the large majority of countries that do not report them (Table 1). There are several reasons why they may not be reported.

- The catch may be mainly by-catch in large-scale commercial longline fisheries and may not be considered consequential. The countries that
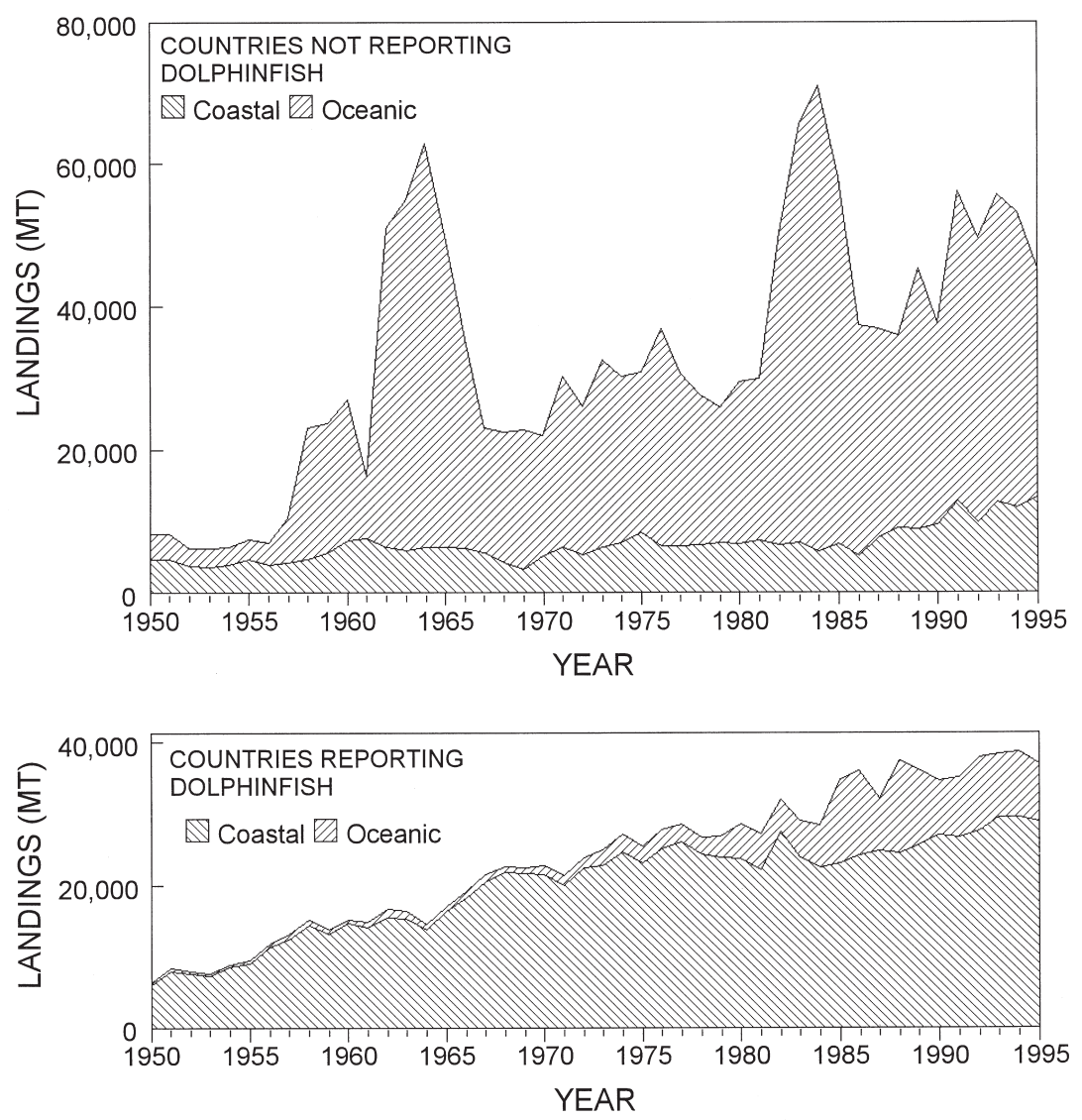

FIG. 4. - The reported landings of coastal and oceanic large pelagics from the Western Atlantic 
report dolphinfish are those for which coastal pelagics are most important (Fig. 4). Countries with well developed small scale trolling and longline fisheries catch a high proportion of coastal pelagics, including dolphinfish.

- The fisheries may be primarily recreational. Recreational catches are not reported by any country except the USA.

- Data collection and reporting systems may not be sufficiently well developed to record, or to report recorded catches to the species level. The data may be collected or estimated at the detailed level but aggregated for reporting because national staff do not appreciate the importance of reporting the data by species.

The literature and FAO data shown in Table 1 suggest that dolphinfish are most important in the eastern Caribbean. Western Caribbean countries, Mexico excepted, do not frequently refer to dolphinfish as a significant species in their national reports and publications describing fisheries. In the eastern Caribbean, fishing areas for dolphinfish appear to be most commonly located to the east of the island chain.

\section{CONCLUSIONS}

Dolphinfish are widely distributed in the western central Atlantic, where they are caught by a wide variety of fisheries: artisanal, small-scale commercial, large-scale commercial and recreational. The growth in all these fleets over the past 20-30 years suggest that exploitation of dolphinfish has been intensifying. The data reported to FAO show a steady increase in landings. However, it is clear that the reported landings are substantially lower than the actual landings. Many countries do not report their dolphinfish landings separately from other species, and few countries report recreational landings.

Although there is no dramatic evidence of a decline in this resource, the lack of information on the quantities of dolphinfish landed should be a matter of urgent concern to all countries that exploit this species.

\section{REFERENCES}

Aiken, K.A. - 1985. A review of pelagic fishery resource assessments in Jamaican waters. FAO Fish. Rept. No. 237 (Suppl.): 174-182.

Anon. - 1985. Report on the December 1983 - December 1984 Fisheries Statistical Project. Fisheries Division, Ministry of Agriculture, Dominica, 8 pp.
Anon. - 1986. Final report on the OAS sponsored 1985 Fisheries Statistical Programme. Fisheries Division, Ministry of Agriculture, Dominica, $12 \mathrm{pp}$.

Appeldoorn, R. and S. Myers. - 1993. Puerto Rico and Hispaniola. In: FAO (ed.), Marine fishery resources of the Antilles, pp. 99158. FAO Fish. Tech. Paper No. 326.

Arocha, F., L.A. Marcano, A. Larez, D. Altuve, and J. Alio. - 1999. The fishery, demographic size structure, and oocyte development of dolphinfish, Coryphaena hippurus, in Venezuela and adjacent waters. Sci. Mar., (this volume).

Bahamas Department of Fisheries. - 1992. Department of Fisheries Annual Report 1992: Statistical Abstract. Department of Fisheries, Nassau, Bahamas: 85 pp.

Baisre, J.S. - 1993. Cuba. In: FAO (ed.), Marine fishery resources of the Antilles., pp. 182-235. FAO Fish. Tech. Paper No. 326.

Brandon, M. - 1987. Marine recreational fishing statistics of the U.S. Virgin Islands, January, 1983 to September, 1985. Proc. Gulf Caribb. Fish. Instit. 38: 665-683.

Brown, H.H. - 1945. The fisheries of the Windward \& Leeward Islands. Development and Welfare in the West Indies. Bulletin No. 20: 98 pp.

Browder, J. and G. Scott. - 1992. History of the western Atlantic U.S. yellowfin fishery. ICCAT Vol. Coll. Sci. Pap. XXXIII:195-202.

Caribbean Commission. - 1952. Fisheries in the Caribbean. Report of the Fisheries Conference, Trinidad, The Caribbean Commission, Kent House, Trinidad: 170 pp.

CFMC. - 1983. Draft Fishery Management Plan, Draft Environmental Impact Statement, Regulatory Analysis for the Coastal Migratory Pelagic Resources. Caribbean Fishery Management Council, Hato Rey, Puerto Rico: 195 pp.

Charlier, P. - 1993. Fisheries information system in Suriname: preliminary analysis of first year's results and guidelines for fisheries management. Fisheries Department, Ministry of Agriculture, Livestock and Fisheries, Suriname, Report No. 2: 76 pp.

De Beauville-Scott, S. - (in press). An overview of recreational fishing in St. Lucia, West Indies. Proc. Gulf Caribb. Fish. Inst., 47.

Eslava, N. and D. Gaertner. - (in press). Caracterization de la flota atunera palangrera Venezolana. Proc. Gulf Caribb. Fish. Instit. 47.

FAO. - 1993 (ed.). Marine fishery resources of the Antilles. FAO Fish. Tech. Pap. 326: 235 pp.

FAO. - 1994. Status of fisheries resources of the world. FAO Fish. Circ.

Friedlander, A. - 1992. A comparison of fishing methods associated with fish aggregating devices (FADS) off Puerto Rico. Proc. Gulf Caribb. Fish. Instit. 42: 233-241.

Garcia, R.E. - 1991. Nicaragua national report. FAO Fish. Rep. No. 431 (Suppl.): $21-25$.

Gobert, B. and G. Domalain. - 1995. Statistical analysis of the fisheries of St. Lucia (West Indies) 1990-1993. Document Scientifique du center ORSTOM de Brest No 77, Decembre 1995: 64 pp.

Gomes, C., R. Mahon, W. Hunte and S. Singh-Renton. - 1998. The role of drifting objects in pelagic fisheries in the southeastern Caribbean. Fish. Res., 34: 47-58.

Guiste, H., G. Domalain and B. Gobert. - 1996. Statistical analysis of the fisheries of Dominica (West indies) 1990-1992. Document Scientifique du center ORSTOM de Brest No 80: 72 pp.

Herrera-Teran, F. - 1988. Venezuela national report. FAO Fish. Rep. No. 376: 26-28.

Instituto Nacional de Pesca y Acuicultura (INPA). - 1993. Boletin estadisticos pesqueros Colombiano. Ministerio de Agricultura, Santa Fe de Bogota, Colombia: 92 pp.

Instituto Nacional de Pesca y Acuicultura (INPA). - 1994. Boletin estadisticos pesqueros Colombiano. Ministerio de Agricultura, Santa Fe de Bogota, Colombia: 71 pp.

Kenny, J.S. and P.R. Bacon. - 1983. Aquatic resources. In: St. G.C. Cooper and P.R. Bacon (eds.), The natural resources of Trinidad and Tobago, pp. 112-143.. Edward Arnold Publ. New York.

Klima. - 1976. A review of the fishery resources of the western central Atlantic. FAO WECAF Studies No. 3: 77 pp.

Machado, G. and R. Jaen. - 1983. General overview of sport fishing in Venezuela. Proc. Gulf. Caribb. Fish. Instit. 35: 179-183.

Mahon, R. - 1987 (ed.). Report and Proceedings of the Expert Consultation on Shared Fishery Resources of the Lesser Antilles Region. FAO Fisheries Report No. 383: 278 pp.

Mahon, R. - 1990. Trends in pelagic fishing effort in the eastern 
Caribbean region: with reference to possible effects on island fisheries. FAO FI: TCP/RLA/8963/Field Document 1: 14 pp.

Mahon, R. - 1993. Lesser Antilles. In: FAO (ed.), Marine fishery resources of the Antilles, pp. 1-98. FAO Fish. Tech. Paper No. 326.

Mahon, R. - 1995. Fisheries for large pelagics in Jamaica: a review and options for development. Unpublished report, CARICOM Fisheries Resource Assessment and Management Program, Belize City, Belize: 46 pp.

Mahon, R. - 1996. Fisheries and research for tunas and tuna-like species in the Western Central Atlantic: Implications of the International Agreement on Conservation and Management of Straddling Fish Stocks and Highly Migratory Fish Stocks. FAO Fish Tech. Pap. No. 357: 72 pp.

Mahon, R. and A. A. Rosenberg (eds.). - 1988. Fishery data collection systems for eastern Caribbean islands. OECS Fishery Report No. 2: 185 pp.

Mahon, R. and S. Singh-Renton. - 1992. Report of the CARICOM Fisheries Resource Assessment and Management Program (CFRAMP). ICCAT Document SCRS/92/154: 4 pp.

Mow de Peters, J.M. - 1988. Colombia national report. FAO Fish. Rep. No. 376 (Suppl).: 13-20.

MRAG. - 1993. Large pelagic fisheries in the Caribbean: Their role in the economies of the U.K. Dependent Territories. Report to the Overseas Administration, Renewable Resource Assessment Group, Imperial College, London: 163 pp.

OECS. - 1996. Fisheries statistical digest No. 4. Organisation of Eastern Caribbean States, St. Lucia; 96 pp.

Olsen, D.A. - 1983. Fishery assessment: St. Kitts and Nevis. Consultant's Report, Caribbean Development Bank, St. Michael, Barbados: $47 \mathrm{pp}$.

Olsen, D.A. and R.S. Wood. - 1983. The marine resource base for recreational fisheries in the Caribbean. Proc. Gulf. Caribb. Fish. Instit. 35: 152-160.

Oxenford, H.A. - 1985. Biology of the dolphin, Coryphaena hippurus, and its implications for the Barbadian fishery. Ph.D. Thesis, University of the West Indies, Cave Hill, Barbados, 366 pp.

Oxenford, H.A. - 1991. Management of marine resources for sustainable development in the Caribbean. In: Moore, E.A. and J. Rudder (eds.), Sustainable Development for the Caribbean: The role of UWI, pp. 120-126. Report on the Sustainable Development Workshop, University of the West Indies, Cave Hill, Barbados.

Oxenford, H.A. and W. Hunte. - 1987. Long-term trends in abundance of the dolphin Coryphaena hippurus, near Barbados. Proc. Gulf. Caribb. Fish. Instit. 38:510-527.

Paez, J. - 1991. Cuba national report. FAO Fish. Rep. No. 431 (Suppl.): 10-20.
Perez, R.N., A.M. Roman, and G. A. Rivera. - 1993. Investigation of the reproductive dynamics and preliminary evaluation of landings data of the dolphinfish, Coryphaena hippurus, $L$. Puerto Rico Department of Natural Resources, Fisheries Research Laboratory, Final Report for Dingell-Johnson Project F26-1: $95 \mathrm{pp}$

Phillips, T and R. Charles. - 1989. Fisheries management and development plan for Guyana 1989-1993. Fisheries Department, Ministry of Agriculture, Guyana, $89 \mathrm{pp}$.

Rodriguez, A. - 1989. Una revision de las pesquerias de tunidos y afines en aquas Cubanas. ICCAT Vol. Coll. Sci. Pap. XXX (2): 462-487.

Roig, M.S. and F.G. de la Maza. - 1952. La pesca en Cuba. Ministry of Agriculture, Cuba: $272 \mathrm{pp}$.

Sacchi, J., A. Lagin, V. Chaudemar, and C. Langlais. - 1981. La pêche des especes pelagiques aux Antilles Françaises, etat actuel et perspective de développement. Science et Pêche, Bull. Inst. Pêches marit. 312: 1-15.

Sahney, A.K. - 1983. Sample survey of the fishing industry in Jamaica - 1981. FAO Fish. Rep. No. 278 (Suppl.): 255-275.

Samlalsingh, S. - 1995. Bioeconomic analysis of the small-scale longline fishery in Grenada. M.Sc. Thesis, UWI, Cave Hill, Barbados: $132 \mathrm{pp}$.

Samlalsingh, S., H.A. Oxenford and J. Rennie. - (in press). A succesful small-scale longline fishery in Grenada. Proc. Gulf Caribb. Fish. Instit., 46: 3-21.

Schmied, R. L. - 1989. The nature and extent of marine recreational fishing and associated development efforts in the Caribbean. Proc. Gulf Caribb. Fish. Instit. 39: 37-52.

Southeast Fisheries Science Center (SEFSC). - 1994. Status of fishery resources off the southeastern United States for 1993. NOAA Technical Memorandum, NMFS-SEFSC: 73 pp.

Singh-Renton, S. and R. Mahon. - 1996. Catch, effort and CPUE trends for offshore pelagic fisheries in and adjacent to the exclusive economic zones (EEZS) of several CARICOM States. CARICOM Fishery Report No. 1: 72 pp.

Stevenson, D.K. - 1981. A review of the marine resources of the Western Central Atlantic Fisheries Commission (WECAFC) region. FAO Fish. Tech. Pap. No. 211: 132 pp.

Walters, R. - 1983. The sport fishery in the British Virgin Islands. Proc. Gulf. Caribb. Fish. Instit. 35: 184-187.

Weidner, D. and Hall, D.N. - 1993. World fishing fleets: an analysis of distant water operations, past, present and future, Vol. IV. US NOAA NMFS, Washington, DC, 513 pp.

Zaneveld. - 1962. Fisheries of the Netherlands Antilles. Proc. Gulf. Caribb. Fish. Instit. 14: 137-170 